\title{
DIVERSIFICATION BENEFITS FROM NEW ZEALAND REAL ESTATE
}

\section{GILBERT NARTEA and CHRIS EVES Lincoln University}

\section{ABSTRACT}

Although the benefits of further diversifying a portfolio of New Zealand financial assets with unsecuritised New Zealand real estate have been confirmed in previous studies, this paper examines the benefits of further diversifying a portfolio by including rural grazing property. Modern portfolio theory is used to determine the benefits of including rural property, as well as the traditional property investment assets, in a diversified investment portfolio based on New Zealand investment assets. In addition, efficient sets generated with and without real estate are compared and found significant return enhancement and risk reduction benefits of adding retail property and farm real estate to the mix. These benefits are robust even when real estate return variance is increased sixfold or when real estate returns are reduced by 20 per cent, suggesting that real estate can reasonably be expected to be a consistent part of risk efficient portfolios.

Keywords: Diversification, unsecuritised real estate, New Zealand, portfolio theory, efficient sets

\section{INTRODUCTION}

There is a growing international consensus that real estate should be part of mixed asset portfolios (Seiler, Webb and Myer, 1999). Investment in real estate can either be through unsecuritised real estate (direct real estate) or through real estate investment trusts (REITS). Fabozzi, Gordon and Hudson-Wilson (2003) showed that real estate can a) reduce risk, b) enhance returns, c) act as a hedge for inflation, and d) deliver strong cash flows to the investor. Lee and Stevenson (2005) also showed that US real investment trusts (REITS) provide both return enhancement and risk reduction benefits. However REITS have been consistently found to be a poor hedge for inflation (see Seiler, Webb and Myer (1999) for an excellent review).

While several studies seem to agree on reasons why real estate should be included in mixed asset portfolios, there is less consensus on how much to invest in real estate. Various figures are suggested ranging from 0 to 83 percent (see for example, Folger, 1984; Hartzell, 1986; Webb and Rubens, 1986, 1987; Irwin and Landa, 1987; Sweeney, 1988; Webb, Curico and Rubens, 1988; Giliberto, 1992, 1993). Inspite of these findings, Bajtelsmit and Worzala (1995) report that the average allocation of real estate in the 
investment portfolio of 159 US pension funds they studied was only $4.48 \%$, with allocations ranging from 1 to 17 percent. This divergence between actual asset allocations and empirical research suggestions has been blamed on lumpiness, illiquidity and high transactions costs of real estate assets, understatement of real estate return volatility in empirical research, and lags in real estate return data (Seiler, Webb and Myer, 1999).

Beyond the traditional real estate sectors, institutional investors also appear to be expanding their focus to non-traditional real estate such as infrastructure and farmland (Newell and Peng, 2006; Newell and Eves, 2007). Several North American studies have suggested the desirability of adding farm real estate (FRE) to a mixed portfolio of financial assets. Barry (1980) found that US farmland has low systematic risk relative to other assets, and is therefore a good candidate for risk reduction in well diversified portfolios. US farmland has also been found to have high returns and negative or low correlations with US stocks, bonds, T-bills and certificates of deposit, making it an ideal asset for diversification (Kaplan, 1985; Young and Barry, 1987; Moss et al., 1987). In Canada, Painter (2000) found that Saskatchewan farmland is negatively correlated with all financial assets considered to be part of the efficient set for medium and high-risk portfolios. In a more recent study, Newell and Eves (2007) found that US real estate provided significant portfolio diversification benefits over the period 1984-2006, and they also report that farmland only enters the optimal portfolio at low levels (less than 9\%) at low portfolio risk levels. This appears to support Hardin and Cheng (2005) who found that that farmland was not necessary in a mixed asset portfolio that already included other classes of real estate.

In New Zealand, Nartea and Dhungana (1998) report a negative correlation between NZ dairy farm returns and NZ bond yields and weak positive correlation with NZ share returns, while Nartea and Pellegrino (1999) also document a negative correlation between NZ sheep and beef farm returns and share returns over the period 1966 to 1996 . These studies suggest that adding farm real estate might improve the risk efficiency of mixed asset portfolios.

Although rural production is a major export income in New Zealand and this industry accounts for up to $60 \%$ of GDP, the inclusion of rural property in studies investigating the desirability of adding traditional and non-traditional real estate in a mixed portfolio of financial assets in a New Zealand context is limited. Hargreaves (1993) identified the trends and profitability levels in rural land prices based on rural land sectors and the issue of corporate foreign rural property ownership in New Zealand was addressed by Mottram (1991); however, studies in relation to the role of rural property in New Zealand investment portfolios has not been adequately addressed.

Research carried out by Newell and De Witt (1997); Newell and Boyd (1995), Newell et al (1996) examined the role of property in New Zealand investment portfolios and concluded that New Zealand traditional property assets offer portfolio diversification 
benefits similar to property in other international investment markets and that New Zealand commercial property can be an inflation-hedge.

Therefore, the purpose of this paper is two-fold. First, we quantify the benefits of adding unsecuritised traditional New Zealand (NZ) real estate, as well as rural grazing land, to a mixed portfolio of NZ shares and bonds using EV analysis of modern portfolio theory, particularly in view of the increasing focus of investment in New Zealand due to the introduction of compulsory superannuation in 2007 (New Zealand Inland Revenue, 2007), with employer compulsory contributions in 2008 and the need for additional property investment vehicles. Prime New Zealand real estate investment properties are currently included in New Zealnd LPTs such as National Property Trust, Kiwi Income Trust, as well as Australian based LPTs including AMP and Goodman.

Second purpose of this paper is to test the robustness of these benefits under several scenarios. The approach is to use historical data for returns of different asset classes to generate risk efficient sets. Efficient sets generated with and without real estate have been compared to determine the magnitude of return enhancement keeping risk constant, as well as the level of risk reduction while maintaining level returns. Robustness tests were also performed to assess diversification benefits under a scenario where a) the return variance of all real estate categories is sextupled, and b) the return of all real estate categories fall by $20 \%$.

This analysis found that a diversified mixed portfolio of NZ financial assets can still benefit significantly from the addition of NZ real estate to the mix through enhanced return or risk reduction benefits. These benefits are robust under both risk-return scenarios considered, suggesting that real estate can reasonably be expected to be a consistent part of risk efficient portfolios.

\section{RESEARCH DESIGN AND DATA}

\section{The model}

The analysis is based on a portfolio of New Zealand shares and bonds with the addition of direct real estate (Office, Industrial, Retail and Rural) to investigate the benefits of including these assets in the mix. This increased diversification is expected to expand the risk efficient frontier by shifting it northwest. Hence, we investigate the incremental impact of the addition of real estate by examining the magnitude by which portfolio returns increase, keeping risk constant, or the amount by which portfolio risk is decreased without diminishing returns.

The traditional full-covariance EV analysis as developed by Markowitz (1952) is used to form risk efficient investment portfolios. A risk efficient portfolio is defined as a combination of assets which maximises the expected returns for a given level of risk 
(measured as variance or standard deviation), or one that minimises the risk level for a desired expected rate of return.

Time series data relating to annual rates of return on shares, bonds and real estate are obtained for the period spanning 1995 to 2005; the return series have been based on annualised figures, as the rural property data is only available annually, unlike the New Zealand Property Council indices that are reported quarterly. Annual rates of return are calculated as the sum of the current return and the capital gain (Sharpe et al. 1999).

\section{Ordinary shares and bonds}

Ordinary shares are represented by the New Zealand Market Index reported in Datastream. Bonds are represented by Datastream ALL lives government bond index.

\section{Real estate}

Several classes of real estate were included in the study - farm real estate, industrial property, office property, composite New Zealand property and retail property. Data from the last four real estate classes were obtained from IPD/Property Council of New Zealand Investment Property Performamce Index.

Farm real estate is represented by sheep and beef operations on grazing farmland. There are 60,000 farms in New Zealand as of 2004, over a third of which are sheep and beef operations covering approximately two-thirds of the 15.5 million hectares of land under occupation.

The total return on farm real estate is the sum of the production rate of return and the capital gain. The production rate of return is the weighted average rate of return on assets for all classes of sheep and beef farms as reported in the New Zealand Sheep and Beef Farm Survey (New Zealand Meat and Wool Board Economic Service, various dates). The Survey involves roughly 500 to 550 farms per year. A sheep and beef farm is defined as a privately operated farm which winters at least 750 sheep or their equivalent stock units in terms of sheep and cattle stock. To the extent that farm rates of return are estimated from group averages, our results are likely to understate the degree of variability faced by the individual farm. The selection of grazing properties was based on the current trend in Australia for institutional rural property ownership being predominately grazing based (Australian Agricultural Company, 2007; Carlson, 2006) . A further factor limiting the choice of farm land use to grazing was the limited income return data available for other rural land uses for the period of the study. This issue will be addressed in the robustness tests to follow. The capital gain component is represented by the annual percentage change in the grazing land price index (Valuation New Zealand, 1995-2005).

A further limitation of adopting the New Zealand grazing rural property returns is the fact that these returns are not based on the standard reporting format of the other real estate investment assets adopted in the research. This has been based on the non-availability of a 
similar rural property investment performance index in New Zealand. Although the construction of the rural property returns are not directly comparable to the other real estate assets analysed, the results still provide a useful comparison for investment decisions.

\section{EMPIRICAL RESULTS}

\section{Comparative risk and return measures}

Table 1 shows the mean, standard deviation, and coefficient of variation (CV) of the annual returns as well as the reward to risk ratio of NZ shares, bonds and real estate from 1995 to 2005. The reward to risk ratio is defined as the return per unit of standard deviation. The data reveals that farm real estate has outperformed NZ shares and bonds as well as all other real estate categories, earning an average annual return of $13.86 \%$. All real estate categories posted higher returns than bonds over the study period except for office property, which earned the same rate as bonds. Likewise, all real estate categories except for commercial and office property earned a higher rate of return than NZ shares over the study period.

Table 1: Risk and return measures for NZ real estate and financial assets, 1995-2005

\begin{tabular}{|c|c|c|c|c|c|}
\hline & $\begin{array}{c}\text { Mean annual } \\
\text { rate of return }{ }^{\mathrm{a}} \\
(\%)\end{array}$ & $\begin{array}{c}\text { Standard } \\
\text { deviation } \\
(\%) \\
\end{array}$ & $\begin{array}{c}\text { Coefficient } \\
\text { of variation } \\
(\%)\end{array}$ & $\begin{array}{l}\text { Reward-to- } \\
\text { risk ratio } \\
\text { (Rank) }\end{array}$ & $\begin{array}{c}\text { Sharpe } \\
\text { Ratio }\end{array}$ \\
\hline Shares & 10.61 & 10.91 & 1.03 & 0.97 & 0.25 \\
\hline Bonds & 7.88 & 4.26 & 0.54 & 1.85 & \\
\hline \multicolumn{6}{|l|}{ Farmland } \\
\hline Income & 2.12 & 1.36 & & & \\
\hline Capital gain & 11.74 & 12.00 & & & \\
\hline Total return & 13.86 & 11.82 & 0.85 & 3.20 & 0.51 \\
\hline \multicolumn{6}{|l|}{ Industrial Property } \\
\hline Income & 9.47 & 1.59 & & & \\
\hline Capital gain & 2.08 & 3.72 & & & \\
\hline Total return & 11.56 & 3.62 & 0.31 & 3.20 & 1.02 \\
\hline \multicolumn{6}{|l|}{ Office Property } \\
\hline Income & 8.36 & 1.06 & & & \\
\hline Capital gain & -0.48 & 4.33 & & & \\
\hline Total return & 7.88 & 3.88 & 0.49 & 2.03 & 0.00 \\
\hline \multicolumn{6}{|l|}{ Composite Property } \\
\hline Income & 8.64 & 1.28 & & & \\
\hline Capital gain & 0.97 & 3.34 & & & \\
\hline Total return & 9.60 & 2.98 & 0.31 & 3.22 & 0.58 \\
\hline \multicolumn{6}{|l|}{ Retail Property } \\
\hline Income & 9.68 & 0.67 & & & \\
\hline Capital gain & 3.67 & 3.07 & & & \\
\hline Total return & 13.35 & 3.24 & 0.24 & 4.12 & 1.69 \\
\hline
\end{tabular}

${ }^{\mathrm{a}}$ All figures in nominal terms.

Using the coefficient of variation as a measure of return volatility, we find that retail property returns are the least volatile while NZ share returns are the most, exhibiting four times the volatility of retail property. With the exception of farm real estate, all the other 
real estate categories exhibited less volatility than NZ bonds, suggesting that NZ real estate was less risky than NZ bonds over the study period.

Using standard deviation of returns as a measure of risk, we can gauge an asset's risk efficiency by its reward to risk ratio. By this measure, retail property is the most risk efficient while NZ shares are the least.

Based on New Bonds being the risk free rate for the period 1995 to 2005, the Sharpe Ratio for the non-property and property investment assets still shows that retail property is the best performing asset on a risk adjusted basis. Table 1 shows that retail property had a Sharpe ratio of 1.69 , with industrial property at 1.02 . Table 1 also shows that rural property had a higher Sharpe ratio at 0.51 compared to New Zealand shares at 0.25 . It is also interesting to note that office property, over the period 1995 to 2005 had a zero return based on comparison to the risk free rate; however, over the period of the study, the real return was positive, with an average annual inflation rate of $2.13 \%$ over the period. The results for composite, office, retail and industrial property are based on capital returns from a valuation based index, with the risk for these returns being subject to valuation smoothing (Newell and Harris, 1996).

Among the real estate categories, only farm real estate exhibited capital gains greater than current income, ie, production return or rental income. Capital gains make up $85 \%$ of the total return to farm real estate, while it only accounts for $14 \%$ of the total return for the rest of the real estate categories.

\section{Correlation matrix}

Table 2 reports the pair-wise correlation coefficients of the asset classes. A negative correlation between assets indicates potentially large diversification benefits from combining them in a portfolio, while these benefits fall as the correlation coefficient approaches positive one. Table 2 shows that real estate generally has a low correlation with shares and bonds, with farm real estate and retail property in particular, exhibiting negative correlation with bonds. Industrial, office, and commercial property returns are generally highly correlated, with correlation coefficients ranging from 0.80 to 0.96 . Retail property and farm real estate returns on the other hand are weakly correlated and also have generally low correlation coefficients with industrial, office and commercial property returns. These coefficients suggest that gains in risk efficiency could be obtained by adding real estate to an investment portfolio of NZ shares and bonds. 
Table 2: Correlation of real estate and financial asset returns, 1995-2005

\begin{tabular}{|c|c|c|c|c|c|c|c|}
\hline & $\begin{array}{c}\text { NZ } \\
\text { Shares }\end{array}$ & Bonds & Farmland & Industrial & Office & Composite & Retail \\
\hline NZ Shares & 1.00 & & & & & & \\
\hline Bonds & 0.21 & 1.00 & & & & & \\
\hline Farmland & 0.21 & -0.16 & 1.00 & & & & \\
\hline Industrial & 0.44 & 0.32 & 0.38 & 1.00 & & & \\
\hline Office & 0.28 & 0.17 & 0.50 & $* 0.80$ & 1.00 & & \\
\hline Composite & 0.35 & 0.07 & 0.47 & $* 0.87$ & $* 0.96$ & 1.00 & \\
\hline Retail & 0.39 & -0.35 & 0.49 & 0.52 & 0.55 & $* 0.71$ & 1.00 \\
\hline
\end{tabular}

* Significant at 5\% level

\section{Benefits of diversification}

Risk-efficient investment portfolios were obtained by solving equation (1) subject to (2), (3) and (4) for alternative values of $Z$. Based on the risk efficient sets, the benefits of diversification are measured by either the magnitude of a) risk reduction, or b) return enhancement.

Base case

Panel A of Table 3 shows that with only shares and bonds in the portfolios, bonds dominate the lower risk-lower return portfolios, while shares dominate the higher riskhigher return portfolios. The investor is able to attain a minimum variance portfolio (MVP) with a return of $8.07 \%$ and a standard deviation of $4.19 \%$ and a maximum return portfolio (MRP) with a return of $10.61 \%$ and a standard deviation of $10.91 \%$. 
Panel A. Efficient portfolios without real estate

\begin{tabular}{lrrrrrrrrrr}
\hline & \multicolumn{1}{c}{ Portfolio } \\
& MVP & 2 & 3 & 4 & 5 & 6 & 7 & 8 & 9 & MRP \\
\hline Assets (\%) & & & & & & & & & & \\
$\quad$ Shares & 7.1 & 17.4 & 27.8 & 38.1 & 48.4 & 58.7 & 69.0 & 79.4 & 89.7 & 100.0 \\
$\quad$ Bonds & 92.9 & 82.6 & 72.2 & 61.9 & 51.6 & 41.3 & 31.0 & 20.6 & 10.3 & 0.0 \\
Expected return (\%) & 8.1 & 8.4 & 8.6 & 8.9 & 9.2 & 9.5 & 9.8 & 10.0 & 10.3 & 10.6 \\
Standard deviation (\%) & 4.2 & 4.3 & 4.7 & 5.4 & 6.1 & 7.0 & 7.9 & 8.9 & 9.9 & 10.9
\end{tabular}

Panel B. Efficient portfolios with real estate

Portfolio

\begin{tabular}{lrrrrrrrrrr} 
& MVP & 2 & 3 & 4 & 5 & 6 & 7 & 8 & 9 & MRP \\
\hline Assets (\%) & & & & & & & & & & \\
Shares & 0.0 & 0.0 & 0.0 & 0.0 & 0.0 & 0.0 & 0.0 & 0.0 & 0.0 & 0.0 \\
Bonds & 40.0 & 34.5 & 29.1 & 23.6 & 18.1 & 12.6 & 7.1 & 1.6 & 0.0 & 0.0 \\
Farmland & 0.0 & 0.0 & 0.0 & 0.0 & 0.0 & 0.0 & 0.0 & 0.0 & 41.2 & 100.0 \\
Industrial & 0.0 & 0.0 & 0.0 & 0.0 & 0.0 & 0.0 & 0.0 & 0.0 & 0.0 & 0.0 \\
Office & 0.0 & 0.0 & 0.0 & 0.0 & 0.0 & 0.0 & 0.0 & 0.0 & 0.0 & 0.0 \\
Commercial & 0.0 & 0.0 & 0.0 & 0.0 & 0.0 & 0.0 & 0.0 & 0.0 & 0.0 & 0.0 \\
Retail & 60.0 & 65.5 & 70.9 & 76.4 & 81.9 & 87.4 & 92.9 & 98.4 & 58.8 & 0.0 \\
Expected return (\%) & 11.2 & 11.5 & 11.8 & 12.1 & 12.4 & 12.7 & 13.0 & 13.3 & 13.6 & 13.9 \\
Standard deviation (\%) & 2.1 & 2.1 & 2.2 & 2.3 & 2.5 & 2.7 & 2.9 & 3.2 & 6.0 & 11.8 \\
\hline a
\end{tabular}

${ }^{a}$ percentage increase in return relative to the corresponding portfolio with the same risk (standard deviation) in the efficient set without real estate

${ }^{\mathrm{b}}$ basis point increase in return relative to the corresponding portfolio with the same risk (standard deviation) in the efficient set without real estate

\section{Shares, bonds and real estate}

Figure 1 plots the risk efficient sets with and without real estate and shows that the introduction of real estate in the portfolios allows the investor to attain a higher return at the same level of risk (standard deviation), ie., its introduction shifts the efficient set northwest. Panel B of Table 3 shows the composition of the risk efficient portfolios when real estate in included in the mix. It is readily apparent that real estate eliminates shares entirely from the efficient portfolios. What is more interesting is that retail property and farm real estate (FRE) dominate the other real estate categories excluding them altogether from the efficient set. This emphasises the fact that not all real estate are the same as found earlier by Webb and Rubens (1987) for the United States (US) market. In fact, retail property also dominates FRE for most of the efficient frontier and only yields some of its 
share in the portfolio at return levels close to the MRP. This finding partly supports those of Harding and Cheng (2005), who found no role for farmland when other classes of real estate are already part of the portfolio.

\section{Figure 1: Efficient sets, with and without real estate, 1995-2005}

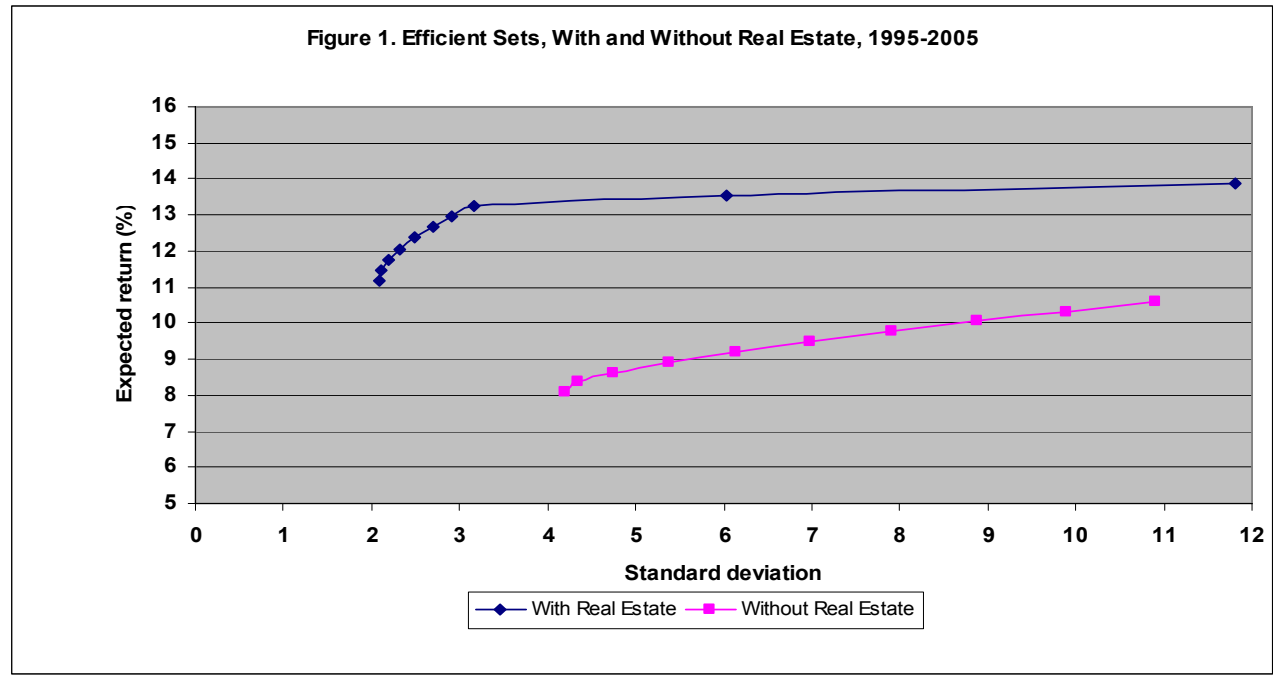

Bonds and retail property dominate the portfolio at the low risk levels (standard deviation ranging from 2.09 to $3.16 \%$ ) with retail property accounting for $60 \%$ of the MVP. Retail property attains a maximum allocation of around $98 \%$ in a portfolio with a risk level (standard deviation) of around 3\%. FRE on the other hand makes up $40 \%$ of a portfolio with a risk level (standard deviation) of $6 \%$ and reaches a maximum weight of $100 \%$ at the MRP. The data suggests that an investor requiring an expected return of 11 to $13 \%$ should invest anywhere from 60 to $90 \%$ of the portfolio in retail property and the rest in bonds. Higher returns could be attained by replacing bonds with farm real estate.

\section{Risk reduction}

The risk reduction benefits can be determined by comparing risk at points of identical returns for portfolios in the efficient sets with and without real estate. An inspection of Figure 1 reveals that the risk reduction benefits can be substantial judging from the vertical distance of the two efficient frontiers. Panel B of Table 3 also shows that with only shares and bonds making up the portfolios, the portfolio with the highest return (MRP) is made up of $100 \%$ shares with an expected return of $10.61 \%$ and a standard deviation of $10.91 \%$. In contrast, with the introduction of real estate into the mix, a 
portfolio consisting of $60 \%$ retail property and $40 \%$ bonds can attain a higher return of $11.16 \%$ and a considerably lower standard deviation of $2.09 \%$. This amounts to an $81 \%$ reduction in risk without sacrificing returns.

\section{Table 3: Risk efficient portfolios}

Panel A. Efficient portfolios without real estate

\begin{tabular}{lrrrrrrrrrr}
\hline & \multicolumn{8}{c}{ Portfolio } \\
& MVP & 2 & 3 & 4 & 5 & 6 & 7 & 8 & 9 & MRP \\
\hline Assets (\%) & & & & & & & & & & \\
$\quad$ Shares & 7.1 & 17.4 & 27.8 & 38.1 & 48.4 & 58.7 & 69.0 & 79.4 & 89.7 & 100.0 \\
$\quad$ Bonds & 92.9 & 82.6 & 72.2 & 61.9 & 51.6 & 41.3 & 31.0 & 20.6 & 10.3 & 0.0 \\
Expected return (\%) & 8.1 & 8.4 & 8.6 & 8.9 & 9.2 & 9.5 & 9.8 & 10.0 & 10.3 & 10.6 \\
$\begin{array}{l}\text { Standard deviation } \\
(\%)\end{array}$ & 4.2 & 4.3 & 4.7 & 5.4 & 6.1 & 7.0 & 7.9 & 8.9 & 9.9 & 10.9
\end{tabular}

Panel B. Efficient portfolios with real estate

\begin{tabular}{lrrrrrrrrrr}
\hline & \multicolumn{10}{c}{ Portfolio } \\
& MVP & 2 & 3 & 4 & 5 & 6 & 7 & 8 & 9 & MRP \\
\hline Assets (\%) & & & & & & & & & & \\
$\quad$ Shares & 0.0 & 0.0 & 0.0 & 0.0 & 0.0 & 0.0 & 0.0 & 0.0 & 0.0 & 0.0 \\
Bonds & 40.0 & 34.5 & 29.1 & 23.6 & 18.1 & 12.6 & 7.1 & 1.6 & 0.0 & 0.0 \\
Farmland & 0.0 & 0.0 & 0.0 & 0.0 & 0.0 & 0.0 & 0.0 & 0.0 & 41.2 & 100.0 \\
Industrial & 0.0 & 0.0 & 0.0 & 0.0 & 0.0 & 0.0 & 0.0 & 0.0 & 0.0 & 0.0 \\
Office & 0.0 & 0.0 & 0.0 & 0.0 & 0.0 & 0.0 & 0.0 & 0.0 & 0.0 & 0.0 \\
Commercial & 0.0 & 0.0 & 0.0 & 0.0 & 0.0 & 0.0 & 0.0 & 0.0 & 0.0 & 0.0 \\
Retail & 60.0 & 65.5 & 70.9 & 76.4 & 81.9 & 87.4 & 92.9 & 98.4 & 58.8 & 0.0 \\
Expected return (\%) & 11.2 & 11.5 & 11.8 & 12.1 & 12.4 & 12.7 & 13.0 & 13.3 & 13.6 & 13.9 \\
Standard deviation & & & & & & & & & & \\
(\%) & 2.1 & 2.1 & 2.2 & 2.3 & 2.5 & 2.7 & 2.9 & 3.2 & 6.0 & 11.8 \\
\hline
\end{tabular}

${ }^{a}$ percentage increase in return relative to the corresponding portfolio with the same risk (standard deviation) in the efficient set without real estate

${ }^{\mathrm{b}}$ basis point increase in return relative to the corresponding portfolio with the same risk (standard deviation) in the efficient set without real estate

\section{Return enhancement}

The return enhancement benefits are shown in Table 4. Panel A shows the efficient portfolios without real estate, while Panel B displays the efficient portfolios with real estate. These return enhancement benefits are measured by comparing returns of portfolios with and without real estate at identical levels of risk (standard deviation) and are expressed as increased returns in terms of both percentage and basis points. The "Increased return (\%)" and "Increased return (basis points)" in Panel B of Table 3 
respectively refer to the percentage (basis points) increase in return relative to the corresponding portfolio in Panel A with the same standard deviation. For example, the increase in return (\%) reported for portfolio 6 is computed as [(13.6-9.5)/9.5] $\times 100=$ 43.2 , with the slight difference in numbers due to rounding error.

Like the risk reduction benefits, the return enhancement benefits shown in Panel B are also economically significant. The increase in return ranges from 31.4 to $58.2 \%$ or 330 to 494 basis points. The return enhancement benefit is largest at the lower end of the frontier, at risk levels defined by a standard deviation of around 4 to $5 \%$.

\section{Table 4: Risk efficient portfolios (return enhancement)}

Panel A. Efficient portfolios without real estate

Portfolio

\begin{tabular}{|c|c|c|c|c|c|c|c|c|c|c|c|c|c|}
\hline \multicolumn{14}{|l|}{ Assets } \\
\hline Shares & & & & & & & & & & & & & \\
\hline & 22.3 & 32.3 & 40.0 & 46.8 & 52.9 & 58.9 & 64.5 & 70.0 & 75.3 & 80.6 & 85.7 & 90.8 & 95.9 \\
\hline Bonds & 77.7 & 67.7 & 60.0 & 53.2 & 47.1 & 41.1 & 35.5 & 30.0 & 24.7 & 19.4 & 14.3 & 9.2 & 4.1 \\
\hline $\begin{array}{l}\text { Expected return } \\
(\%)\end{array}$ & 8.5 & 8.8 & 9.0 & 9.2 & 9.3 & 9.5 & 9.5 & 9.8 & 9.9 & 10.1 & 10.2 & 10.4 & 10.5 \\
\hline $\begin{array}{l}\text { Standard } \\
\text { deviation }(\%)\end{array}$ & 4.5 & 5.0 & 5.5 & 6.0 & 6.5 & 7.0 & 7.5 & 8.0 & 8.5 & 9.0 & 9.5 & 10.0 & 10.5 \\
\hline
\end{tabular}

Panel B. Efficient portfolios with real estate

\begin{tabular}{|c|c|c|c|c|c|c|c|c|c|c|c|c|c|}
\hline \multicolumn{14}{|c|}{ Portfolio } \\
\hline & 1 & 2 & 3 & 4 & 5 & 6 & 7 & 8 & 9 & 10 & 11 & 12 & 13 \\
\hline \multicolumn{14}{|l|}{ Assets } \\
\hline \multicolumn{14}{|l|}{ Shares } \\
\hline \multicolumn{14}{|l|}{ Bonds } \\
\hline \multirow[b]{2}{*}{ Farmland } & 0.0 & 0.0 & 0.0 & 0.0 & 0.0 & 0.0 & 0.0 & 0.0 & 0.0 & 0.0 & 0.0 & 0.0 & 0.0 \\
\hline & 15.9 & 29.3 & 35.2 & 40.8 & 46.2 & 51.6 & 56.8 & 62.0 & 67.1 & 72.1 & 77.1 & 82.1 & 87.0 \\
\hline Industrial & 0.0 & 0.0 & 0.0 & 0.0 & 0.0 & 0.0 & 0.0 & 0.0 & 0.0 & 0.0 & 0.0 & 0.0 & 0.0 \\
\hline Office & 0.0 & 0.0 & 0.0 & 0.0 & 0.0 & 0.0 & 0.0 & 0.0 & 0.0 & 0.0 & 0.0 & 0.0 & 0.0 \\
\hline Commercial & 0.0 & 0.0 & 0.0 & 0.0 & 0.0 & 0.0 & 0.0 & 0.0 & 0.0 & 0.0 & 0.0 & 0.0 & 0.0 \\
\hline Retail & 84.1 & 70.7 & 64.8 & 59.2 & 53.8 & 48.4 & 43.2 & 38.0 & 32.9 & 27.9 & 22.9 & 17.9 & 13.0 \\
\hline $\begin{array}{l}\text { Expected return } \\
(\%)\end{array}$ & 13.4 & 13.5 & 13.5 & 13.6 & 13.6 & 13.6 & 13.6 & 13.7 & 13.7 & 13.7 & 13.7 & 13.8 & 13.8 \\
\hline $\begin{array}{l}\text { Standard } \\
\text { deviation (\%) }\end{array}$ & 4.5 & 5.0 & 5.5 & 6.0 & 6.5 & 7.0 & 7.5 & 8.0 & 8.5 & 9.0 & 9.5 & 10.0 & 10.5 \\
\hline \multirow{2}{*}{$\begin{array}{l}\text { Increase in return } \\
(\%)^{\mathrm{a}} \\
\text { Increase in return } \\
\text { (basis points) }^{\mathrm{b}}\end{array}$} & 58.2 & $\begin{array}{l}54.1 \\
473 .\end{array}$ & 50.8 & 48.1 & 45.7 & 43.5 & 44.2 & 39.6 & 37.8 & 36.1 & 34.5 & 32.9 & 31.4 \\
\hline & 494.3 & 7 & 455.8 & 440.2 & 426.1 & 412.6 & 417.9 & 387.6 & 375.6 & 363.9 & 352.2 & 340.9 & 329.6 \\
\hline
\end{tabular}




\section{Role of other types of real estate}

Figure 2 shows efficient sets formed if only one type of real estate is added to a portfolio of shares and bonds. It shows that no matter what type of real estate is added to the portfolio, diversification benefits accrue. Recognising that the further to the northwest is an efficient frontier, the better it is, it is clear that adding retail property to the portfolio generates the best frontier. This is followed by a frontier containing industrial, farm, commercial, and office property, in that order. The addition of office property to the portfolio, however, provides only a marginal improvement in the efficient frontier.

\section{Figure 2: Efficient sets, with and without real estate by categories, 1995-2005}

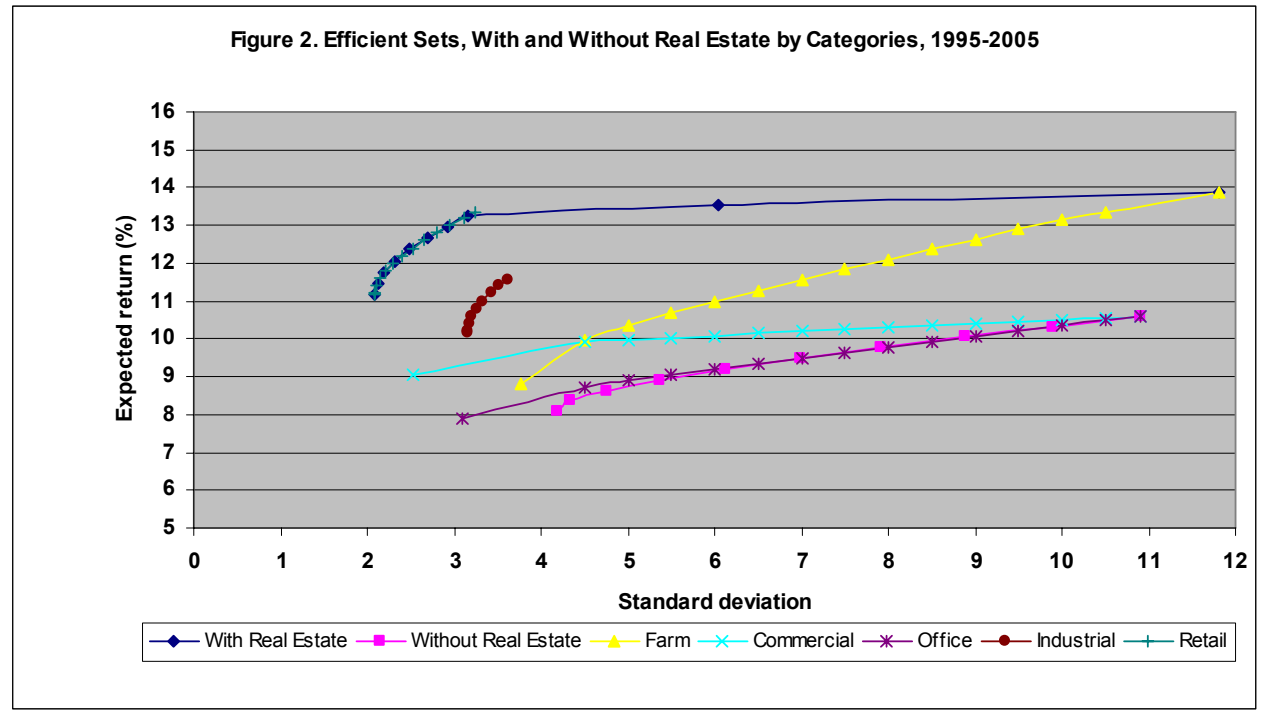

\section{Robustness tests}

It has been suggested that real estate forms part of mixed asset portfolios due to the understatement of real estate risk in empirical research attributed to measurement errors (Webb and Rubens,1987; Fisher et al.,1994; Corgel and de Roos,1999); hence we test the robustness of these diversification benefits to changes in our original FRE risk and return estimates.

\section{Increase in real estate return variance}

To address the issue of possible underestimation of real estate risk, we investigate the impact on the efficient set of a six-fold increase in the variance of real estate returns. 
Panel A of Table 5 shows the composition of the efficient portfolios in the base case, while Panel B shows the portfolios when the variance of returns of all real estate categories are increased six-fold. Panel B shows that assets making up the efficient set when real estate return variance is increased are virtually the same as in the base case with retail property, bonds, and FRE dominating the risk efficient portfolios. However, the proportion of retail property drops in the low to mid level risk as increase in allocation. The maximum weight attained by retail property is around $96 \%$, while FRE still makes up $100 \%$ of the MRP. Bonds attain a maximum allocation of $71 \%$ at the MVP compared with $40 \%$ in the base case. Shares still have no part to play in the efficient set.

\section{Table 5: Robustness tests}

Panel A. Efficient portfolios with real estate (Base Case)

\begin{tabular}{|c|c|c|c|c|c|c|c|c|c|c|}
\hline \multicolumn{11}{|c|}{ Portfolio } \\
\hline & MVP & 2 & 3 & 4 & 5 & 6 & 7 & 8 & 9 & MRP \\
\hline \multicolumn{11}{|l|}{ Assets } \\
\hline Shares & 0.0 & 0.0 & 0.0 & 0.0 & 0.0 & 0.0 & 0.0 & 0.0 & 0.0 & 0.0 \\
\hline Bonds & 40.0 & 34.5 & 29.1 & 23.6 & 18.1 & 12.6 & 7.1 & 1.6 & 0.0 & 0.0 \\
\hline Farmland & 0.0 & 0.0 & 0.0 & 0.0 & 0.0 & 0.0 & 0.0 & 0.0 & 41.2 & 100.0 \\
\hline Industrial & 0.0 & 0.0 & 0.0 & 0.0 & 0.0 & 0.0 & 0.0 & 0.0 & 0.0 & 0.0 \\
\hline Office & 0.0 & 0.0 & 0.0 & 0.0 & 0.0 & 0.0 & 0.0 & 0.0 & 0.0 & 0.0 \\
\hline Commercial & 0.0 & 0.0 & 0.0 & 0.0 & 0.0 & 0.0 & 0.0 & 0.0 & 0.0 & 0.0 \\
\hline Retail & 60.0 & 65.5 & 70.9 & 76.4 & 81.9 & 87.4 & 92.9 & 98.4 & 58.8 & 0.0 \\
\hline Expected return (\%) & 11.2 & 11.5 & 11.8 & 12.1 & 12.4 & 12.7 & 13.0 & 13.3 & 13.6 & 13.9 \\
\hline Standard deviation (\%) & 2.1 & 2.1 & 2.2 & 2.3 & 2.5 & 2.7 & 2.9 & 3.2 & 6.0 & 11.8 \\
\hline
\end{tabular}

Panel B. Efficient portfolios with real estate (6x Variance)

\begin{tabular}{|c|c|c|c|c|c|c|c|c|c|c|}
\hline \multicolumn{11}{|c|}{ Portfolio } \\
\hline & MVP & 2 & 3 & 4 & 5 & 6 & 7 & 8 & 9 & MRP \\
\hline \multicolumn{11}{|l|}{ Assets } \\
\hline Shares & 0.0 & 0.0 & 0.0 & 0.0 & 0.0 & 0.0 & 0.0 & 0.0 & 0.0 & 0.0 \\
\hline Bonds & 71.4 & 62.4 & 53.5 & 44.5 & 35.5 & 26.6 & 17.6 & 8.2 & 0.0 & 0.0 \\
\hline Farmland & 0.0 & 0.0 & 0.0 & 0.0 & 0.0 & 0.0 & 0.0 & 0.0 & 3.8 & 100.0 \\
\hline Industrial & 0.0 & 0.0 & 0.0 & 0.0 & 0.0 & 0.0 & 0.0 & 1.2 & 0.0 & 0.0 \\
\hline Office & 0.0 & 0.0 & 0.0 & 0.0 & 0.0 & 0.0 & 0.0 & 0.0 & 0.0 & 0.0 \\
\hline Commercial & 0.0 & 0.0 & 0.0 & 0.0 & 0.0 & 0.0 & 0.0 & 0.0 & 0.0 & 0.0 \\
\hline Retail & 28.6 & 37.6 & 46.5 & 55.5 & 64.5 & 73.4 & 82.4 & 90.6 & 96.2 & 0.0 \\
\hline Expected return (\%) & 9.4 & 9.9 & 10.4 & 10.9 & 11.4 & 11.9 & 12.4 & 12.9 & 13.4 & 13.9 \\
\hline Standard deviation (\%) & 3.1 & 3.2 & 3.6 & 4.1 & 4.8 & 5.5 & 6.3 & 7.1 & 8.2 & 29.0 \\
\hline
\end{tabular}

Panel C. Efficient portfolios with real estate (20\% reduction in real estate returns)

\begin{tabular}{|c|c|c|c|c|c|c|c|c|c|c|}
\hline \multicolumn{11}{|c|}{ Portfolio } \\
\hline & MVP & 2 & 3 & 4 & 5 & 6 & 7 & 8 & 9 & MRP \\
\hline \multicolumn{11}{|l|}{ Assets } \\
\hline Shares & 0.0 & 0.0 & 0.0 & 0.0 & 0.0 & 0.0 & 0.0 & 0.0 & 0.0 & 0.0 \\
\hline Bonds & 40.0 & 33.9 & 27.9 & 21.8 & 15.7 & 9.6 & 3.6 & 0.0 & 0.0 & 0.0 \\
\hline Farmland & 0.0 & 0.0 & 0.0 & 0.0 & 0.0 & 0.0 & 0.0 & 17.1 & 58.5 & 100.0 \\
\hline Industrial & 0.0 & 0.0 & 0.0 & 0.0 & 0.0 & 0.0 & 0.0 & 0.0 & 0.0 & 0.0 \\
\hline Office & 0.0 & 0.0 & 0.0 & 0.0 & 0.0 & 0.0 & 0.0 & 0.0 & 0.0 & 0.0 \\
\hline Commercial & 0.0 & 0.0 & 0.0 & 0.0 & 0.0 & 0.0 & 0.0 & 0.0 & 0.0 & 0.0 \\
\hline Retail & 60.0 & 66.1 & 72.1 & 78.2 & 84.3 & 90.4 & 96.4 & 83.0 & 41.5 & 0.0 \\
\hline Expected return (\%) & 9.6 & 9.7 & 9.9 & 10.1 & 10.2 & 10.4 & 10.6 & 10.7 & 10.9 & 11.1 \\
\hline Standard deviation (\%) & 2.1 & 2.1 & 2.2 & 2.4 & 2.6 & 2.8 & 3.1 & 4.1 & 7.7 & 11.8 \\
\hline
\end{tabular}




\section{Fall in real estate returns}

Next, we investigate the effect of a $20 \%$ across the board decline in real estate returns. The results reported in Panel C of Table 5 shows that a $20 \%$ fall in real estate returns expectedly lowers the attainable portfolio returns. However, real estate is still a major part of the efficient portfolios. Bonds, retail property and FRE are still the dominant components of the portfolio. Retail property dominates over the entire portfolio as in the base case and attains a maximum weight of $96 \%$ at a risk level (standard deviation) of 3\%. This dominance is relinquished to FRE only at the MRP with a risk level of around $11.8 \%$. The MRP is still 100\% FRE and shares are still kept out of the efficient set.

Overall, in both risk-return scenarios considered in this study, real estate enters the risk efficient portfolios at an economically significant level. Therefore, we conclude that even in a relatively small market economy such as New Zealand, retail property and FRE can reasonably be expected to be a consistent part of risk efficient portfolios.

\section{CONCLUSION}

This study investigated the benefits of further diversifying a mixed portfolio of financial assets with direct real estate. The results show that given the low correlation between real estate and financial assets, the risk-return tradeoffs of such portfolios can be improved significantly. However, not all real estate are the same as retail property and FRE dominate the other real estate categories, excluding them altogether from the efficient portfolios. Retail property is a consistent part of the risk efficient portfolios over most of the efficient frontier, with FRE only becoming important at the higher end.

The diversification benefits measured in terms of risk reduction and return enhancement are robust to an increase in real estate return variance or a decline in real estate returns, suggesting that we can reasonably expect retail property and FRE to be a consistent part of risk efficient portfolios.

The practical implication of our findings is that investors can significantly enhance their portfolio risk-return tradeoffs, particularly by reducing risk, through diversification into direct real estate. Direct real estate therefore appears to deserve more serious consideration by investment practitioners that it has been accorded in the past.

\section{REFERENCES}

Australian Agricultural Company. (2007) Financial Report 2007.

Bajtelsmit, V. and Worzala, E. (1995). Real estate allocation in pension fund portfolios, Journal of Real Estate Portfolio Management, 1, 25-38. 
Barry, P.J. (1980). Capital asset pricing and farm real estate, American Journal of Agricultural Economics, 62, 549-553.

Carlson, W. (2006) Surfing the rural property boom. Property Update 2006. National Australia Bank.

Corgel, J.B., and deRoos, J.A. (1999), Recovery of Real Estate Returns for Portfolio allocation, Journal of Real Estate Finance and Economics, 18, 279-296.

Fabozzi, F., Gordon, J. and Hudson-Wilson, S. (2003) Why real estate? The Journal of Portfolio Management, 29, 12-25.

Fisher, J.D., Geltner, D.M., and Webb, R.B. (1994) Value Indices of Commercial Real Estate: A Comparison of Index Construction Methods, Journal of Real Estate Finance and Economics, 9, 137-164.

Folger, H.R. (1984) 20\% in real estate: Can theory justify it? The Journal of Portfolio Management, Winter, 6-13.

Giliberto, M.(1992). Real estate risk and return: 1991 Survey results, Real Estate Research Paper. New York,: Salomon Brothers.

Giliberto, M. (1993). Measuring real estate returns: The hedged REIT Index, Journal of Portfolio Management, Spring 94-99.

Hartzell, D., (1986). Real Estate in the Portfolio, New York: Salomon Brothers.

Hardin, W., and Cheng, P. (2005) Farmland in a mixed-asset portfolio: A meansemivariance approach, Journal of Real Estate Portfolio Management, 11, 187-195.

Irwin, S. and Landa, D. (1987). Real estate, futures and gold as portfolio assets, The Journal of Portfolio Management, 13, 29-34.

Inland Revenue New Zealand (2007) Kiwi Saver. http://www.kiwisaver.govt.nz/kiwisaver-schemes/

Kaplan, H.M. (1985). Farmland as a portfolio investment. The Journal of Portfolio Management 11, 73-79.

Lee, S. and Stevenson, S. (2006). Real estate in the mixed-asset portfolio: the question of consistency, Journal of Property Investment and Finance, 24, 123-135. 
Lee, S. and Stevenson, S. (2005). The case for REITS in the mixed-asset portfolio in the short and long run, Journal of Real Estate Portfolio Management, 11, 55-81.

Lins, D., Kowalski, A., and Hoffman, C. (1992). Institutional investment diversification: foreign stocks vs. U.S. farmland, Proceedings of Regional Research

Committee NC-161, Department of Agricultural Economics, Kansas State University, Manhattan, Kansas.

Markowitz, H.M. (1952). Portfolio selection, Journal of Finance, 12, 77-91.

Moss, C.B., Featherstone, M., and Baker, T.G. (1987). Agricultural assets in an efficient multi-period investment portfolio, Agricultural Finance Review, 47, 82-94.

Mottram, R. (1991) Foreign investment in New Zealand's rural sector. New Zealand Valuers Journal, September 1991, pp20-23.

Nartea, G.V., and Dhungana, B.R. (1998). Diversifiable and nondiversifiable risk in New Zealand dairy farming, Proceedings of the NZ Farm Management Society Annual Conference; 18-20 Nov 1998, Waikato University, Hamilton, 172-182.

Nartea, G.V., and Pellegrino, J.M. (1999). Off-farm investment in financial assets as a risk response for New Zealand sheep and beef farms, Research Report 99/07, Farm and Horticultural Management Group, Division of Applied Management and Computing, Lincoln University.

Newell, G and Boyd, T (1995). Inflation-hedging attributes of New Zealand commercial property. New Zealand Valuers Journal, December 1995, 50-54.

Newell, G. and De Witt, D. (1997). Assessing New Zealand commercial property performance. New Zealand Valuers Journal, July 1997, 31-36.

Newell, G. and Eves, C. (2007). The role of US farmland in real estate portfolios, Journal of Real Estate Portfolio Management, 13, 4, 317-328.

Newell, G., Macfarlane, J. and Harris, A. (1996). The impact of valuation-smoothing on New Zealand commercial property risk. New Zealand Valuers Journal, July 1996, 48.

Newell, G. and Peng, H. W. (2006). The significance of emerging property sectors in property portfolios. Pacific Rim Property Research Journal, 12, 2, 177-197.

New Zealand Meat and Wool Board Economic Service (various dates). The New Zealand Sheep and Beef Farm Survey, Wellington. Selected issues. 
Painter, M.J. (2000). Should Saskatchewan farmland be part of your investment portfolio?, Canadian Journal of Agricultural Economics, 48, 39-50.

Seiler, M., Webb, J., Myer, N. (1999). Diversification issues in real estate investment, Journal of Real Estate Literature, 7, 163-179.

Sharpe, W.F., Alexander, G.J., and Bailey, J.V. (1999). Investments, 6th ed, Prentice-Hall, New Jersey.

Sweeney, F. (1988) 20\% in Property - a Viable Strategy? Estates Gazette, 13 February, 26-28.

Valuation New Zealand. Rural Property Sales Statistics. Wellington. Selected issues.

Webb, J.R., and Rubens, J.H (1986). Portfolio considerations in the valuation of real estate, AREUEA Journal, 14(3), 465-495.

Webb, J.R., and Rubens, J.H (1987). How much in real estate? A surprising answer, The Journal of Portfolio Management, Spring, 10-14.

Webb, J.R., Curico, R.J. and Rubens, J.H (1988). Diversification gains from including real estate in mixed-asset portfolios, Decision Sciences, 19, 434-452.

Young, R. and Barry, P.J. (1987). Holding financial assets as a risk response: a portfolio analysis of Illinois grain farms, North Central Journal of Agricultural Economics, 9, 7784. 